\section{Pacific Northwest}

National Laboratory

Operated by Battelle for the

U.S. Department of Energy

\title{
Final Report West Valley High-Level Waste Tank Lay-Up
}

\author{
M. Elmore \\ C. Henderson*
}

June 29, 2001

*Jacobs Engineering Group, Inc.

Prepared for the U.S. Department of Energy under Contract DE-AC06-76RL01830 


\title{
DISCLAIMER
}

This report was prepared as an account of work sponsored by an agency of the United States Government. Neither the United States Government nor any agency thereof, nor Battelle Memorial Institute, nor any of their employees, makes any warranty, express or implied, or assumes any legal liability or responsibility for the accuracy, completeness, or usefulness of any information, apparatus, product, or process disclosed, or represents that its use would not infringe privately owned rights. Reference herein to any specific commercial product, process, or service by trade name, trademark, manufacturer, or otherwise does not necessarily constitute or imply its endorsement, recommendation, or favoring by the United States Government or any agency thereof, or Battelle Memorial Institute. The views and opinions of authors expressed herein do not necessarily state or reflect those of the United States Government or any agency thereof.

\author{
PACIFIC NORTHWEST NATIONAL LABORATORY \\ operated by \\ BATTELLE \\ for the \\ UNITED STATES DEPARTMENT OF ENERGY \\ under Contract DE-AC06-76RL01830
}

Printed in the United States of America

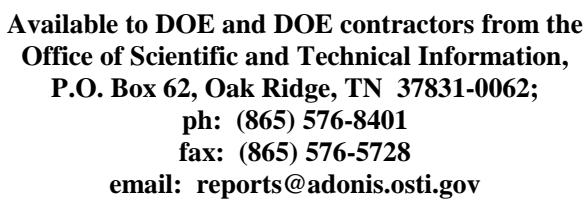

Available to the public from the National Technical Information Service, U.S. Department of Commerce, 5285 Port Royal Rd., Springfield, VA 22161 ph: (800) 553-6847 fax: $(703) 605-6900$

email: orders@ntis.fedworld.gov

online ordering: http://www.ntis.gov/ordering.htm 
PNNL-13897

\section{Final Report West Valley High-Level Waste Tank Lay-Up}

June 29, 2001

Prepared for

Tanks Focus Area and

the U.S. Department of Energy

under Contract DE-AC06-76RL01830

Jacobs Engineering Group, Inc., and

Pacific Northwest National Laboratory

Richland, Washington 99352 


\section{CONTENTS}

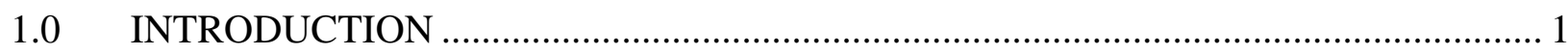

2.0 EVALUATION CRITERIA FOR SELECTION OF PREFERRED OPTION .................. 2

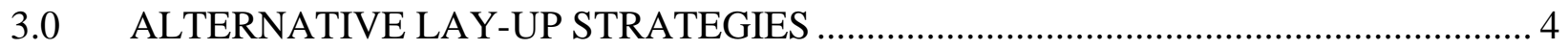

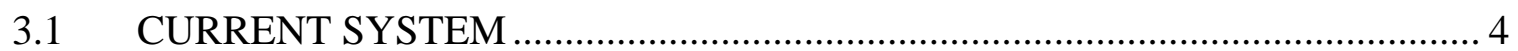

3.2 CATHODIC PROTECTION FOR EXTERNAL TANK SURFACES ................... 4

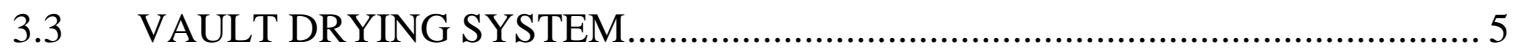

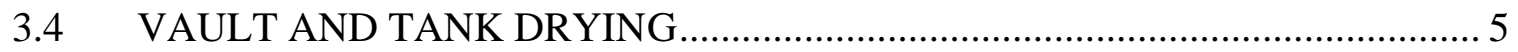

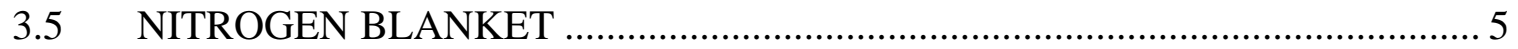

3.6 NITROGEN BLANKET WITH OXYGEN REMOVAL ……............................ 5

3.7 ARGON OR OTHER HIGH DENSITY INERT GAS INSTEAD

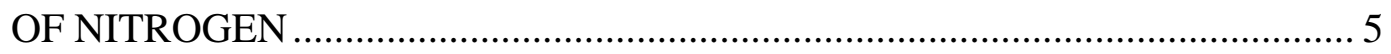

3.8 ARGON BLANKET WITH CATHODIC PROTECTION …………………........ 6

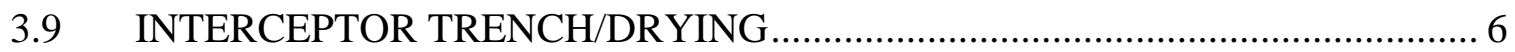

3.10 TRENCH/INFILTRATION BARRIER/DRYING ........................................... 6

3.11 INFILTRATION BARRIER/DRYING/ENHANCED PUMPING......................... 6

3.12 GROUNDWATER BARRIER/DRYING ………....................................... 7

3.13 INFILTRATION BARRIER/DRYING ......................................................... 7

3.14 CORROSION INHIBITORS IN THE WATER OUTSIDE THE TANKS ........... 7

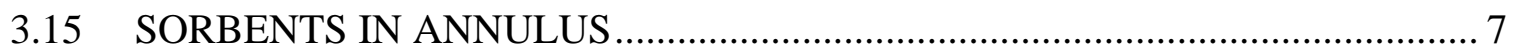

3.16 SORBENTS WITH CATHODIC PROTECTION ……………........................... 7

3.17 LOW-STRENGTH GROUT …………………......................................

3.18 LOW-STRENGTH GROUT/DRYING ....................................................... 8

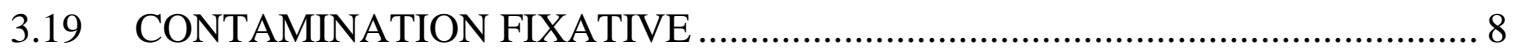

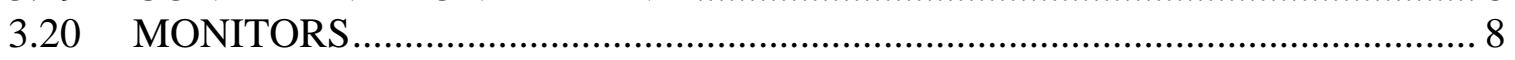

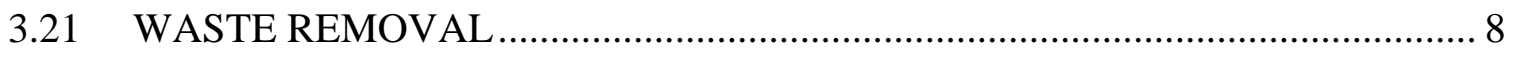

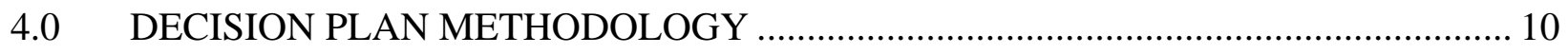

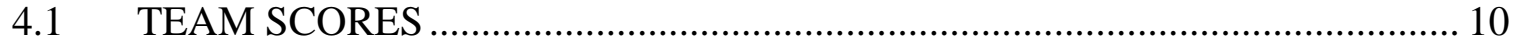

4.2 DEMONSTRATION OF METHODOLOGY …….......................................... 13

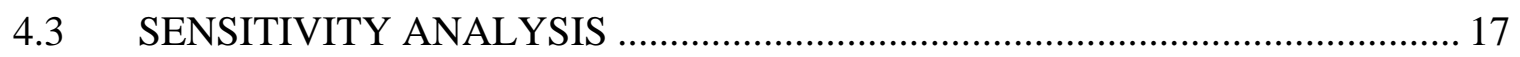

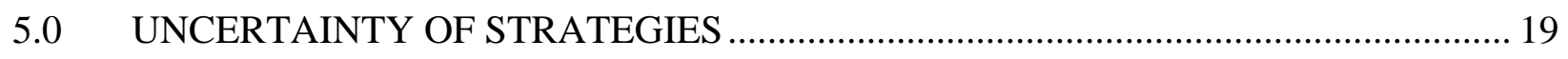

6.0 WORKSHOP AT WEST VALLEY DEMONSTRATION PROJECT............................. 21

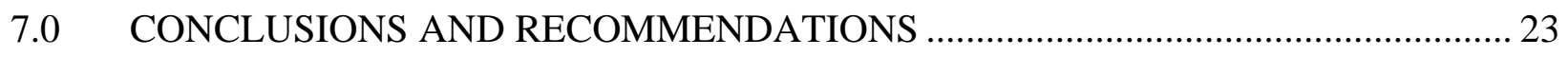

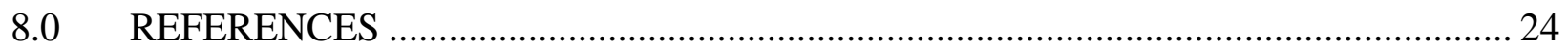




\section{FIGURE}

1. Methodology for Identifying Preferred Lay-Up Approach ............................................. 10

\section{TABLES}

1. Alternative Strategies for West Valley Demonstration Project Tank Lay-Up ................... 9

2. Team Scoring Sheet ............................................................................................. 11

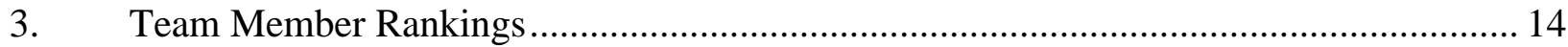

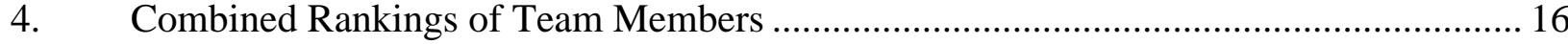

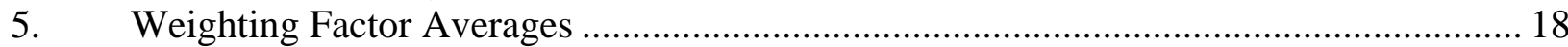




\subsection{INTRODUCTION}

This report documents completion of Milestone A.4-1, "Issue Tank Lay-Up Strategies for WVDP Final Report," in Technical Task Plan RL30WT21A, "Post-Retrieval and Pre-Closure HLW Tank Lay-Up." This task was a collaborative effort among Pacific Northwest National Laboratory, Jacobs Engineering Group Inc., and West Valley Nuclear Services. The primary objective of the overall task was to develop and evaluate conceptual strategies for preclosure lay-up of the two large high-level waste storage tanks at the West Valley Demonstration Project.

Functions and requirements for tank lay-up were developed and previously documented in Functions and Requirements for WVDP Lay-Up (Henderson 2001a [Letter Report \#1]). These functions and requirements served as the basis for criteria to evaluate potential lay-up options documented in West Valley High-Level Waste Tank Lay-Up Strategies (Henderson 2001b [Letter Report \#2]). A methodology for ranking the alternative lay-up strategies was described in Decision Plan for West Valley High-Level Waste Tank Lay-up (Henderson 2001c [Letter Report \#3]).

Several actions were identified for possible implementation to provide assurance of maintaining the West Valley Demonstration Project tanks in a safe, stable, and minimum maintenance mode that does not compromise final closure options. Alternative strategies for this lay-up period were then identified which are either individual actions or combinations of actions.

Criteria were identified for assessing the alternative strategies. The criteria represent requirements or desired features of any strategy selected. The lay-up strategy selected should provide the best balance among the evaluation criteria for placing the tanks in a safe, stable lay-up mode.

A methodology was developed for ranking the potential strategies. The methodology provides a consensus ranking even with wide variations in scores from individual team members as long as the number of team members is large enough. A minimum of 8 team members is recommended, and 10 to 12 members would be better. Because of the number and types of technical issues associated with the strategies, the evaluation team should consist of a broad spectrum of technical experts and decision makers.

The methodology is applicable to determining preferred lay-up approaches at other U.S. Department of Energy sites. Some of the alternative strategies identified for West Valley should also be considered for implementation at the other sites, and some would not be. Each site has unique characteristics that would require unique considerations for lay-up.

This final report contains a summary of all the previous reports and a summary of a workshop held at the West Valley Demonstration Project site to discuss the results of the sample scoring of alternative strategies (Letter Report \#3). 


\subsection{EVALUATION CRITERIA FOR SELECTION OF PREFERRED OPTION}

The following criteria were selected for evaluating alternative strategies for tank lay-up (Letter Report \#1). The criteria represent requirements or desired features of any strategy selected. The methodology includes assigning weighting factors to the criteria to distinguish their relative importance. Two criteria were expanded into subcriteria for the sample scoring.

- Comply with regulations and permit requirements - All regulations and permit requirements must be complied with during the lay-up period.

- Prevent release of tank contents to the groundwater - There shall be no release of radioactive or hazardous materials to the groundwater. This is a consideration during any preparatory activities and during the lay-up period.

- Ensure acceptable risk to workers and the public

- Short-term risk: The risks associated with the installation of any new equipment required for the selected option must be as low as reasonably achievable.

- Long-term risk: The selected option should result in a reduced risk to workers and the public during the lay-up period.

- Maintain integrity of the tanks - The ability of the tanks to continue to contain the waste residual must be maintained. Corrosion of the tanks must be controlled, and the structural integrity of the tanks must be ensured.

- Establish a safe operating envelope during temporary lay-up - The operational requirements during the lay-up period must continue to be within safe limits, but reduced monitoring and surveillance should be considered in evaluating options.

\section{- Control costs}

- Capital costs of new equipment or modifications to existing systems.

- Routine operating costs during the lay-up period.

- Utilize accepted methods and technologies - The preferred option should be based on proven construction methods and demonstrated technologies.

- Avoid production of secondary wastes during construction and operation - Options that may produce secondary wastes, especially radioactive wastes that will require further treatment and disposal, should be generally avoided.

- Preserve future options for decontamination and final closure - The selected lay-up option must maintain the ability to sample the waste, perform additional waste removal, and complete additional decontamination of the tanks if necessary. Also, the lay-up option selected must not preclude candidate final closure options, such as in-place stabilization or complete tank removal. 
- Gain acceptance for lay-up - The selected option must be acceptable to stakeholders. Any changes to permits or other requirements must be acceptable to regulatory agencies.

- Reduce monitoring and surveillance - Reductions in monitoring and surveillance, consistent with requirements, is desired. 


\subsection{ALTERNATIVE LAY-UP STRATEGIES}

Several alternative actions were identified to provide for continued safe storage of the residual waste in the tanks prior to final closure (Letter Report \#2). The lay-up strategy selected should provide the best balance among the evaluation criteria for placing the tanks in a safe, stable, and minimum maintenance mode that does not compromise final closure options. The following strategies were identified for consideration (Letter Report \#2).

\subsection{CURRENT SYSTEM}

The historical methods of corrosion control have been to periodically remove water from the containment pan, control the $\mathrm{pH}$ and nitrite/nitrate ratio of the liquid inside the tanks, and maintain a nitrogen purge inside the vaults. The corrosion rate of the tank internals is believed to be controlled in the range of 0.013 to $0.025 \mathrm{~mm} / \mathrm{yr}\left(0.5\right.$ to $\left.1.0 \mathrm{mpy}^{1}\right)$ (Chang et al. 1999). However, $\mathrm{pH}$ and nitrite/nitrate limits have not been rigorously maintained since waste retrieval operations began, decreasing the level of the confidence of corrosion control.

Pumps are currently used to remove water from outside and inside the tank vaults. However, there will continue to be a concern that corrosion to the external surfaces of the tanks could eventually result in penetrations during the lay-up period. Corrosion of the external tank walls is primarily from the wet conditions inside the vaults. General corrosion rates determined from corrosion coupons are generally less than $0.075 \mathrm{~mm} / \mathrm{yr}(3 \mathrm{mpy})$ and the highest measured rate is $0.188 \mathrm{~mm} / \mathrm{yr}$ (7.4 mpy) (Chang et al. 1999). The external pitting corrosion rate has been estimated at up to $0.3 \pm 0.075 \mathrm{~mm} / \mathrm{yr}$ (12 $\pm 3 \mathrm{mpy}$ ) (Chang et al. 1998). If this rate has been experienced since the tanks were built, there may be little remaining corrosion allowance at locations prone to pitting.

The nitrogen inerting system has been in operation since August 1996. The oxygen concentration in the vault exhaust gas has been maintained at about $13.5 \%$ to $15.5 \%$ (oxygen concentration in air is $21 \%$ ) even though the system was originally designed to maintain the oxygen concentration below 0.99\% (WVNS-DC-065). Assuming an even distribution of nitrogen in the vaults, use of the system has resulted in an estimated decrease in the external corrosion rate of tank 8D-1 by about 33\% (Chang et al. 1999). The nitrogen inerting system also reduces the concentration of other impurities in the gas surrounding the tanks, such as sulfur dioxide, that can also accelerate corrosion.

\subsection{CATHODIC PROTECTION FOR EXTERNAL TANK SURFACES}

Addition of cathodic protection to the tanks has been assessed. One alternative method for cathodic protection identified is to use the containment pan as the sacrificial anode.

The tank $8 \mathrm{D}-2$ containment pan is known to have a hole in it, so use as a sacrificial anode would be reasonable because its original purpose is already compromised. There are several technical and engineering issues that must be resolved before this option could be selected. These include (1) galvanic corrosion on the bottom of the tank; (2) runaway voltage with the impressed current

${ }^{1} \mathrm{mpy}=$ mils per year; a mil is $1 / 1000$ of an inch. 
system; (3) protection of welds; and (4) assurance that no electrical shorts are present (e.g., pan pump, dip tubes) (Chang et al. 1999).

\subsection{VAULT DRYING SYSTEM}

General textbook corrosion rates of carbon steel in water are generally 0.075 to $0.20 \mathrm{~mm} / \mathrm{yr}$ ( 3 to $8 \mathrm{mpy}$ ) and pitting corrosion rates are generally 2.5 to 3.5 times the general corrosion rate. External tank corrosion could be virtually eliminated if the tank surfaces were kept dry. The criterion would be to maintain the relative humidity below $30 \%$ in the air surrounding the tanks (Chang et al. 1998). The drying system would include a dehumidifier and heater for air forced into the vaults. The exhaust air leaving the vaults would pass through high-efficiency particulate air filters.

\subsection{VAULT AND TANK DRYING}

An additional enhancement to also reduce corrosion inside the tanks is to install drying systems both inside the vaults and inside the tanks. Drying the inside of the tanks could result in contamination of the exhaust air by particles of dried solids in the tanks being suspended by the airflow through the tanks. However, once all the liquid inside the tanks was evaporated, only a very low-flow of heated, dehumidified air would be required to maintain low humidity inside the tanks. Keeping the tank internal surfaces the same temperature as the external surfaces would also prevent condensation of water on the tanks' external walls.

\subsection{NITROGEN BLANKET}

The current nitrogen inerting system has not been effective in maintaining the desired concentration of oxygen in the vault below $0.9 \%$ as specified in the design criteria (WVNS-DC-065). Sealing the vault as well as possible and then adding additional amounts of cold nitrogen to displace air from the vault should result in a more effective blanket and lower oxygen concentrations.

\subsection{NITROGEN BLANKET WITH OXYGEN REMOVAL}

Oxygen removal from the gas surrounding the tanks to a low level (the original design criterion for the nitrogen purge was less than $0.9 \%$ oxygen) may provide adequate protection without additional measures taken to keep the vaults dry. An efficient nitrogen blanket (recirculating system) would also be required for this option. Recirculated blanket gas could be passed through a device to remove oxygen. Such a system would be efficient only if air in-leakage is significantly reduced.

\subsection{ARGON OR OTHER HIGH DENSITY INERT GAS INSTEAD OF NITROGEN}

This is an enhancement of using argon instead of nitrogen to improve the displacement of oxygen and other corrosion-inducing gases from the vaults because argon is heavier than air. Proper use of an argon blanket should not require additional capability for oxygen removal. This option has been considered in the past, as early as 1997 (Meess and Chang 1997). 


\subsection{ARGON BLANKET WITH CATHODIC PROTECTION}

This is an enhancement of using argon instead of nitrogen to improve the displacement of oxygen and other corrosion-inducing gases from the vaults in combination with cathodic protection for additional assurance of corrosion control.

\subsection{INTERCEPTOR TRENCH/DRYING}

One of the primary methods of preventing or significantly reducing corrosion on the outside of the tanks is to maintain very low humidity in the vaults. To do this, the ingress of water into the vaults must be prevented. The principal source of water into the vaults appears to be from percolation of rainwater and snowmelt through the soil layer above the vaults and groundwater flow in the soil/sand layer above the compacted clay layer. One method to significantly reduce this infiltration is to divert runoff and groundwater flow. This could be accomplished by installing an interceptor trench down to the compacted clay layer upgradient of the tanks. This trench would be filled with coarse gravel and perforated pipe would be installed at the bottom of the trench to collect and remove excess water. The trench would be connected to a culvert to carry water to an appropriate location downgradient from the tanks and vaults. This would be a totally passive system. Pumping of water from the vaults and the well between the vaults could be eliminated or significantly reduced.

\subsection{TRENCH/INFILTRATION BARRIER/DRYING}

To increase the effectiveness of a trench, a domed clay cap, roof, or some other cover barrier could be added above the vaults to divert rainwater and snowmelt to the trench rather than infiltrating through the soil to the vaults.

A principal source of water ingress into the tank vaults appears to be from infiltration from above the vaults. A cover to divert rainwater away from the area would be effective in preventing this water from entering the vaults. This barrier could be a clay cap, a membrane, a roof, or some other cover. Installation of a barrier above the vaults is complicated by the superstructure that was installed to support the mobilization pumps and penetrations into the soil above the tanks and vaults.

\subsection{INFILTRATION BARRIER/DRYING/ENHANCED PUMPING}

To ensure that water will not infiltrate into the vaults from groundwater around and below the vaults, the capability to pump water from the gravel bed below the vaults could be maintained or enhanced. Water is currently pumped from a well between the vaults, but the water table is not pumped to below the bottom of the vaults. The hydrology is not known well enough to determine the volume of water that would need to be pumped to maintain the water table below the level of the vaults. More frequent operation of the current system or additional wells and pumps may be needed. Elimination of surface water infiltration and possibly also a reduction in groundwater flow (as described in the preceding sections) may be necessary for this option to be effective. 
If the combination of a trench, infiltration barrier and drying system was not effective, then additional pumping of water from inside and below the vaults could be instituted. The need for additional pumping is unlikely.

\subsection{GROUNDWATER BARRIER/DRYING}

A solid barrier to groundwater flow could be installed if more positive exclusion of groundwater from the vaults is needed. This barrier could be a solid grout wall, a frozen soil barrier, or a viscous liquid barrier.

A barrier around the vaults may be a more positive means to preclude water intrusion than would an interceptor trench. However this would be a much more costly approach and may not be necessary. Also, ponding (perched water) could accumulate behind the barrier.

\subsection{INFILTRATION BARRIER/DRYING}

A barrier above the tanks would be very effective in preventing water intrusion into the vaults. The combination of a barrier above the vaults and a drying system (no interceptor trench or barrier) may be adequate for keeping the vault humidity within an acceptable level. This is dependent on the amount of water that could infiltrate the vaults from groundwater flow alone, which appears to be quite small.

\subsection{CORROSION INHIBITORS IN THE WATER OUTSIDE THE TANKS}

Adding corrosion inhibitors to water in the containment pans may reduce the corrosion on the outer walls below the liquid level. The same corrosion inhibitors would not be effective for reducing corrosion in the high-humidity vapor space above the liquid level.

\subsection{SORBENTS IN ANNULUS}

An ion exchange and/or sorbent material could be added to the secondary containment pan and/or the vault to capture the radioactive species before they could migrate outside the vault. Additional information would be required to determine if a combination of materials could be selected which would be effective for all the species of concern.

\subsection{SORBENTS WITH CATHODIC PROTECTION}

This would be a relatively low-cost option of adding a cathodic protection system and also sorbents for added protection in the unlikely event of a leak. However, reliable corrosion control with cathodic protection alone is uncertain.

\subsection{LOW-STRENGTH GROUT}

The objective of this option is to provide a method for temporarily fixing the residual waste in the tank. Nearly all the residual liquid would have to be removed before the grout was added. A low-strength grout would be necessary so that it could be removed in the future if final closure requires additional decontamination of the tanks or complete removal of the tanks. Adequate mixing of the grout with the residual waste has not been demonstrated. 


\subsection{LOW-STRENGTH GROUT/DRYING}

This would be the combination of adding a low-strength grout and a drying system for the tanks and vaults. The drying system would be very effective in reducing corrosion and the grout would stabilize the radionuclides and reduce or possibly prevent leakage even if a penetration in the tank wall developed.

\subsection{CONTAMINATION FIXATIVE}

Another option for temporary stabilization of the residual material in the tank would be to spray a coating to prevent any suspension of contamination. This option could be used in combination with the option to keep the inside of the tanks dry to prevent corrosion or to reduce contaminated solids suspension if the tank contents are allowed to dry during the lay-up period. In fact, the tank contents would first have to be dry before a fixative could be applied. The drying system would reduce corrosion and the fixative would stabilize the radionuclides and prevent dispersion into the off-gas system.

\subsection{MONITORS}

Radiation and/or contamination monitors in the tanks or vaults would indicate changes in conditions and possible leaks. There are several monitors on the market that could be installed to give early warning of a tank failure. A gamma monitor would need to be shielded from the background radiation inside the tank, or an alpha and/or beta monitor could be used.

Continuous corrosion monitors could also be installed in the tanks and vaults. These monitors would provide an indication of accelerated corrosion due to unexpected changes.

Depending on the composition of waste in the West Valley Demonstration Project carbon-steel tanks, the tanks may be susceptible to nitrate ion-induced stress corrosion cracking. Monitoring and maintaining adequate nitrite/nitrate ratio and hydroxide ion levels prevents this degradation. Sensors that could monitor all three species could reduce the costs of current baseline sampling and laboratory analysis methods and could minimize the addition of corrosion inhibitor solution. Savannah River Site personnel are currently evaluating a Raman spectroscopy-based method for in situ analysis of $\mathrm{OH}^{-}, \mathrm{NO}_{2}^{-}$, and $\mathrm{NO}_{3}^{-}$.

\subsection{WASTE REMOVAL}

Very aggressive decontamination could be employed prior to temporary tank lay-up. Removal of all but a very small amount of residual contamination may preclude the need for any further action prior to final closure. This option might have a lower lay-up cost than other options that require continued operation of equipment (such as the nitrogen purge system) and surveillance. However, the criteria for what constitutes adequate decontamination are not established and any residual contamination could present a risk to the environment.

Table 1 is a summary of the lay-up strategies considered for the West Valley Demonstration Project tanks. 
Table 1. Alternative Strategies for West Valley Demonstration Project Tank Lay-Up

\begin{tabular}{|c|c|c|c|c|c|c|c|c|c|c|c|c|c|c|c|c|c|c|c|c|}
\hline Strategy & 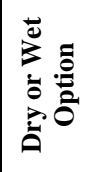 & 势 & 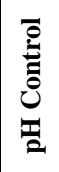 & 告 & 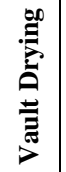 & 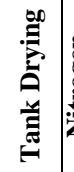 & 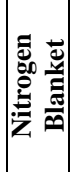 & 量 & 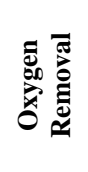 & 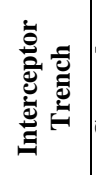 & 这 & & 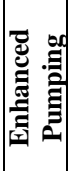 & 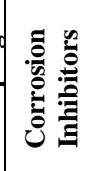 & 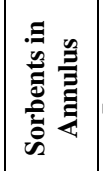 & 焉 & 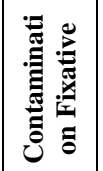 & 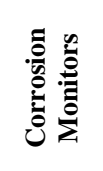 & 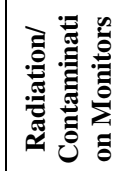 & 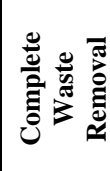 \\
\hline Current System & Wet & $\mathrm{x}$ & $\mathrm{X}$ & & & & & & & & & & & & & & & & & \\
\hline Cathodic Protection & Wet & $\mathrm{x}$ & $\mathrm{X}$ & $\mathrm{X}$ & & & & & & & & & & & & & & & & \\
\hline Vault Drying & Dry & & $\mathrm{X}$ & & $\mathrm{x}$ & & & & & & & & & & & & & & & \\
\hline Vault \& Tank Drying & Dry & & & & $\mathrm{x}$ & $\mathrm{X}$ & & & & & & & & & & & & & & \\
\hline Nitrogen Blanket & Wet & & $\mathrm{X}$ & & & & $\mathrm{x}$ & & & & & & & & & & & & & \\
\hline $\begin{array}{l}\text { Nitrogen Blanket w/Oxygen } \\
\text { Removal }\end{array}$ & Wet & & $\mathrm{x}$ & & & & $\mathrm{x}$ & & $\mathrm{x}$ & & & & & & & & & & & \\
\hline Argon Blanket & Wet & & $\mathrm{x}$ & & & & & $\mathrm{x}$ & & & & & & & & & & & & \\
\hline $\begin{array}{l}\text { Argon Blanket w/Cathodic } \\
\text { Protection }\end{array}$ & Wet & & $\mathrm{x}$ & $\mathrm{X}$ & & & & $\mathrm{x}$ & & & & & & & & & & & & \\
\hline Interceptor Trench/Drying & Dry & & $\mathrm{x}$ & & $\mathrm{x}$ & & & & & $\mathrm{x}$ & & & & & & & & & & \\
\hline $\begin{array}{l}\text { Trench/Infiltration } \\
\text { Barrier/Drying }\end{array}$ & Dry & & $\mathrm{x}$ & & $\mathrm{x}$ & & & & & $\mathrm{x}$ & & $\mathrm{x}$ & & & & & & & & \\
\hline $\begin{array}{l}\text { Trench/Infiltration } \\
\text { Barrier/Drying/Enhanced } \\
\text { Pumping }\end{array}$ & Dry & & $\mathrm{x}$ & & $\mathrm{x}$ & & & & & $\mathrm{x}$ & & $\mathrm{x}$ & $\mathrm{x}$ & & & & & & & \\
\hline Groundwater Barrier/Drying & Dry & & $\mathrm{x}$ & & $\mathrm{x}$ & & & & & & $\mathrm{x}$ & & & & & & & & & \\
\hline Infiltration Barrier/Drying & Dry & & $\mathrm{x}$ & & $\mathrm{x}$ & & & & & & & $\mathrm{x}$ & & & & & & & & \\
\hline Corrosion Inhibitors in Vault & Wet & $\mathrm{x}$ & $\mathrm{x}$ & & & & & & & & & & & $\mathrm{x}$ & & & & & & \\
\hline Sorbents in Annulus & Wet & $\mathrm{x}$ & $\mathrm{X}$ & & & & & & & & & & & & $\mathrm{x}$ & & & & & \\
\hline $\begin{array}{l}\text { Sorbents with Cathodic } \\
\text { Protection }\end{array}$ & Wet & $\mathrm{x}$ & $\mathrm{x}$ & $\mathrm{x}$ & & & & & & & & & & & $\mathrm{x}$ & & & & & \\
\hline Low Strength Grout & Wet & $\mathrm{x}$ & & & & & & & & & & & & & & $\mathrm{x}$ & & & & \\
\hline Low Strength Grout/Drying & Dry & & & & $\mathrm{x}$ & $\mathrm{x}$ & & & & & & & & & & $\mathrm{x}$ & & & & \\
\hline $\begin{array}{l}\text { Contamination } \\
\text { Fixative/Drying }\end{array}$ & Dry & & & & $\mathrm{x}$ & $\mathrm{x}$ & & & & & & & & & & & $\mathrm{x}$ & & & \\
\hline Monitors & Wet & & $\mathrm{X}$ & & & & & & & & & & & & & & & $\mathrm{x}$ & $\mathrm{x}$ & \\
\hline Waste Removal & Wet & & & & & & & & & & & & & & & & & & & $\mathrm{x}$ \\
\hline
\end{tabular}




\subsection{DECISION PLAN METHODOLOGY}

A methodology for ranking the strategies was developed. The methodology consists of scoring each strategy with each of the selection criteria. The scoring matrix is shown as Table 2. Team members would supply weighting factors from 1 to 5 for each of the criteria, and scores from 1 to 5 for how well each strategy meets the criteria. A total score for each strategy is then calculated as a sum of the products of each score times the associated criterion weighting factor.

A flowchart of the methodology is shown in Figure 1.

Figure 1. Methodology for Identifying Preferred Lay-Up Approach

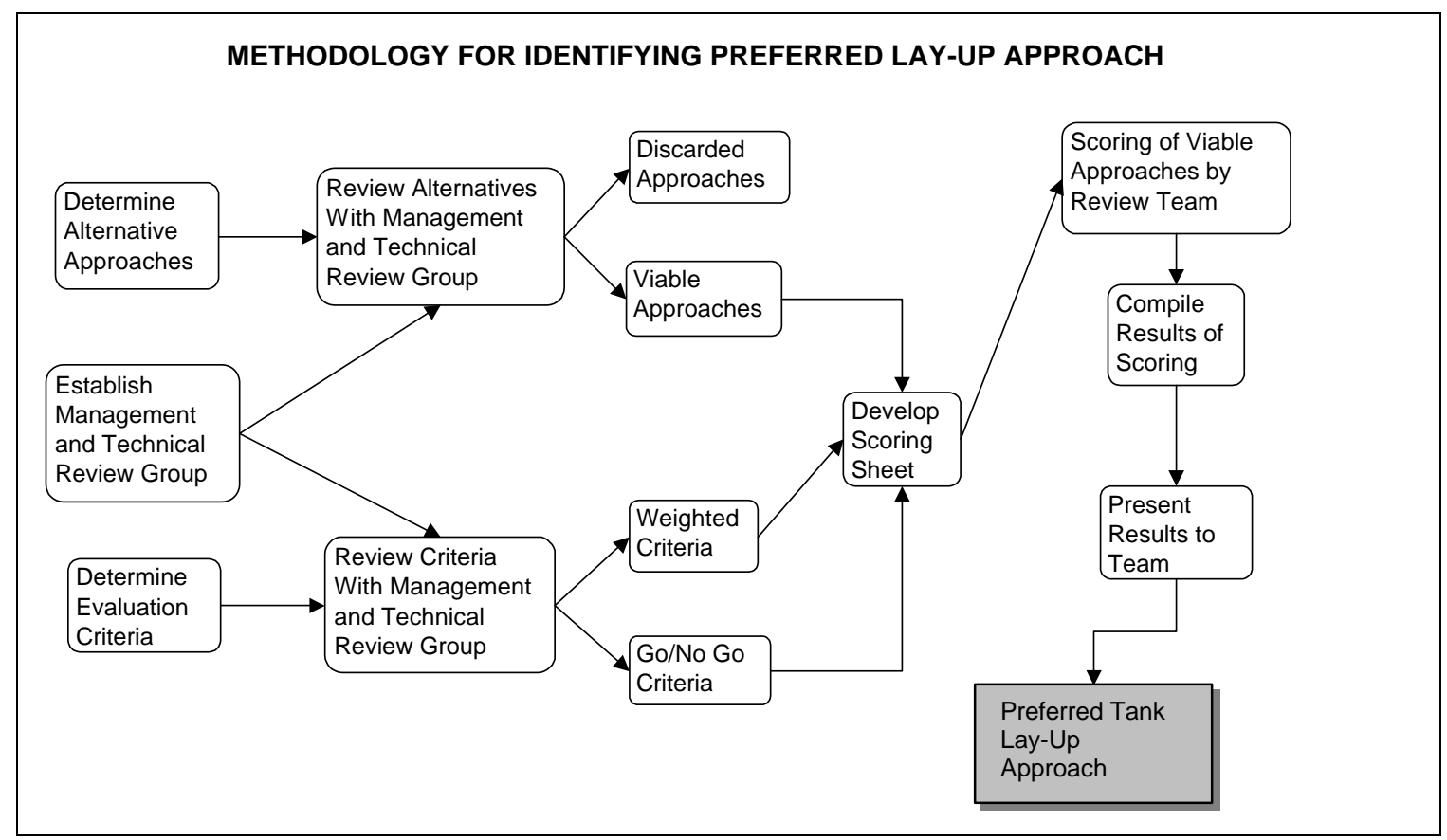

\subsection{TEAM SCORES}

The individual team rankings resulting from the scoring sheets can be depicted by ranking the total score from highest to lowest. A combined ranking of the strategies from the team member rankings can then be compiled. The combined ranking is based on assigning a score of 5 to each \#1 ranking, a score of 4 to each \#2 ranking, etc. down to a score of 1 for each \#5 ranking. Many of the lowest-ranked strategies can be eliminated from further consideration, or the strategies can be reconfigured to combine elements into a strategy or strategies oriented at meeting the tank lay-up goals. 
Table 2. Team Scoring Sheet (2 Sheets)

\begin{tabular}{|c|c|c|c|c|c|c|c|c|c|c|c|c|c|c|c|}
\hline $\begin{array}{c}\text { Evaluation } \\
\text { Criteria-----> }\end{array}$ & $\begin{array}{l}\text { Compliance } \\
\text { with } \\
\text { Regulations } \\
\text { and Permits }\end{array}$ & $\begin{array}{c}\text { Prevent } \\
\text { Release of } \\
\text { Contents }\end{array}$ & $\begin{array}{c}\text { Acceptable } \\
\text { Risk (Short } \\
\text { Term) }\end{array}$ & $\begin{array}{c}\text { Acceptable } \\
\text { Risk (Long } \\
\text { Term) }\end{array}$ & $\begin{array}{c}\text { Maintain } \\
\text { Tank } \\
\text { Integrity }\end{array}$ & $\begin{array}{c}\text { Safe } \\
\text { Operating } \\
\text { Envelope }\end{array}$ & $\begin{array}{c}\text { Capital } \\
\text { Cost }\end{array}$ & $\begin{array}{l}\text { Operating } \\
\text { Cost }\end{array}$ & $\begin{array}{c}\text { Proven } \\
\text { Methods and } \\
\text { Technologies }\end{array}$ & $\begin{array}{c}\text { Minimize } \\
\text { Secondary } \\
\text { Waste }\end{array}$ & $\begin{array}{l}\text { Preserve } \\
\text { Closure } \\
\text { Options }\end{array}$ & $\begin{array}{l}\text { Regulatory } \\
\text { and } \\
\text { Stakeholder } \\
\text { Acceptance }\end{array}$ & $\begin{array}{c}\text { Reduced } \\
\text { Monitoring } \\
\quad \text { and } \\
\text { Surveillance }\end{array}$ & $\begin{array}{c}\text { Certainty } \\
\text { of } \\
\text { Strategy }\end{array}$ & \\
\hline STRATEGY & & & & & & & & & & & & & & & SCORE \\
\hline Maximum Score & 5 & 5 & 5 & 5 & 5 & 5 & 5 & 5 & 5 & 5 & 5 & 5 & 5 & 5 & \\
\hline Current System & & & & & & & & & & & & & & & \\
\hline $\begin{array}{l}\text { Cathodic } \\
\text { Protection }\end{array}$ & & & & & & & & & & & & & & & \\
\hline Vault Drying & & & & & & & & & & & & & & & \\
\hline $\begin{array}{l}\text { Vault \& Tank } \\
\text { Drying }\end{array}$ & & & & & & & & & & & & & & & \\
\hline Nitrogen Blanket & & & & & & & & & & & & & & & \\
\hline Argon Blanket & & & & & & & & & & & & & & & \\
\hline $\begin{array}{l}\text { Argon Blanket } \\
\text { w/Cathodic } \\
\text { Protection }\end{array}$ & & & & & & & & & & & & & & & \\
\hline $\begin{array}{l}\text { Interceptor } \\
\text { Trench/Drying }\end{array}$ & & & & & & & & & & & & & & & \\
\hline $\begin{array}{l}\text { Trench/Infiltration } \\
\text { Barrier/Drying }\end{array}$ & & & & & & & & & & & & & & & \\
\hline $\begin{array}{l}\text { Trench/Infiltration } \\
\text { Barrier/ } \\
\text { Drying/Enhanced } \\
\text { Pumping }\end{array}$ & & & & & & & & & & & & & & & \\
\hline $\begin{array}{l}\text { Groundwater } \\
\text { Barrier/Drying }\end{array}$ & & & & & & & & & & & & & & & \\
\hline
\end{tabular}


Table 2. Team Scoring Sheet (2 Sheets)

\begin{tabular}{|c|c|c|c|c|c|c|c|c|c|c|c|c|c|c|c|}
\hline $\begin{array}{c}\text { Evaluation } \\
\text { Criteria------> }\end{array}$ & $\begin{array}{c}\text { Compliance } \\
\text { with } \\
\text { Regulations } \\
\text { and Permits }\end{array}$ & $\begin{array}{c}\text { Prevent } \\
\text { Release of } \\
\text { Contents }\end{array}$ & $\begin{array}{c}\text { Acceptable } \\
\text { Risk (Short } \\
\text { Term) }\end{array}$ & $\begin{array}{c}\text { Acceptable } \\
\text { Risk (Long } \\
\text { Term) }\end{array}$ & $\begin{array}{c}\text { Maintain } \\
\text { Tank } \\
\text { Integrity }\end{array}$ & $\begin{array}{c}\text { Safe } \\
\text { Operating } \\
\text { Envelope }\end{array}$ & $\begin{array}{l}\text { Capital } \\
\text { Cost }\end{array}$ & $\begin{array}{l}\text { Operating } \\
\text { Cost }\end{array}$ & $\begin{array}{c}\text { Proven } \\
\text { Methods and } \\
\text { Technologies }\end{array}$ & $\begin{array}{l}\text { Minimize } \\
\text { Secondary } \\
\text { Waste }\end{array}$ & $\begin{array}{l}\text { Preserve } \\
\text { Closure } \\
\text { Options }\end{array}$ & $\begin{array}{c}\text { Regulatory } \\
\text { and } \\
\text { Stakeholder } \\
\text { Acceptance }\end{array}$ & $\begin{array}{c}\text { Reduced } \\
\text { Monitoring } \\
\quad \text { and } \\
\text { Surveillance }\end{array}$ & $\begin{array}{c}\text { Certainty } \\
\text { of } \\
\text { Strategy }\end{array}$ & \\
\hline $\begin{array}{l}\text { Weighting Factor } \\
(1-5)--->\end{array}$ & & & & & & & & & & & & & & & \\
\hline STRATEGY & & & & & & & & & & & & & & & SCORE \\
\hline Maximum Score & 5 & 5 & 5 & 5 & 5 & 5 & 5 & 5 & 5 & 5 & 5 & 5 & 5 & 5 & \\
\hline $\begin{array}{l}\text { Infiltration } \\
\text { Barrier/Drying }\end{array}$ & & & & & & & & & & & & & & & \\
\hline $\begin{array}{l}\text { Corrosion } \\
\text { Inhibitors in Vault }\end{array}$ & & & & & & & & & & & & & & & \\
\hline $\begin{array}{l}\text { Sorbents in } \\
\text { Annulus }\end{array}$ & & & & & & & & & & & & & & & \\
\hline $\begin{array}{l}\text { Sorbents with } \\
\text { Cathodic } \\
\text { Protection }\end{array}$ & & & & & & & & & & & & & & & \\
\hline $\begin{array}{l}\text { Low Strength } \\
\text { Grout }\end{array}$ & & & & & & & & & & & & & & & \\
\hline $\begin{array}{l}\text { Low Strength } \\
\text { Grout/Drying }\end{array}$ & & & & & & & & & & & & & & & \\
\hline $\begin{array}{l}\text { Contamination } \\
\text { Fixative/Drying }\end{array}$ & & & & & & & & & & & & & & & \\
\hline Monitors & & & & & & & & & & & & & & & \\
\hline Waste Removal & & & & & & & & & & & & & & & \\
\hline
\end{tabular}




\subsection{DEMONSTRATION OF METHODOLOGY}

A team was selected with a broad range of experience to provide scores on the matrix that were used to demonstrate the methodology. These sample scores provided a starting point for demonstrating the methodology. The ranking of strategies resulting from these scores are reported only to demonstrate the methodology and are not intended as a recommendation of preferred strategies.

The scoring team was comprised of three personnel from the Richland Jacobs Engineering Group Inc. Office, three from the Denver Jacobs Office and three from Pacific Northwest National Laboratory. The disciplines represented were: (1) Chemist, (2) Chemical Engineer, (3) Civil Engineer, (4) Environmental Engineer, (5) Corrosion Engineer, (6) Hydrogeologist, (7) Mechanical Engineer, and (8) Regulatory Specialist (two).

The individual team rankings resulting from the scoring sheets are shown in Table 3. Team member B did not provide weighting factors, so the averages of the weighting factor scores from the other team members were used to determine scores for team member B. There are some interesting results from the individual scoring sheets. Note that team member A scored the grout options last, while team members $\mathrm{F}$ and $\mathrm{G}$ ranked them first. This may demonstrate a lack of understanding of this option by one or more of the team members. Scoring was completed on an individual basis and compiled for this report without a meeting to develop consensus for the weighting factors or scores. When the actual ranking of strategies is done, a meeting of all parties should be convened to discuss the scores and rankings and resolve such differences. The ranking from the raw scores and sensitivity analysis should merely serve as the starting point for the discussion.

The results shown in Table 3 indicate that the team members favored the strategy of using an interceptor trench, infiltration barrier, and vault drying. This may be a result of this strategy being one of the more extensive in terms of the number of actions taken to prevent water from entering the vaults. The addition of enhancement pumping to these three actions also scored high. The options of using grout to stabilize the tank contents also scored well. The waste removal option also scored in the top five.

A combined ranking of the strategies from the team member rankings is shown in Table 4. The combined ranking is based on assigning a score of 5 to each \#1 ranking, a score of 4 to each \#2 ranking, etc. down to a score of 1 for each \#5 ranking. Table 4 shows that the strategy of installing an interceptor trench in combination with an infiltration barrier and vault drying is clearly preferred. There is very little difference in the scores for the strategies ranked second through fifth. There are a number of strategies that ranked low indicating that there was little confidence by any of the team members that the strategies as described would meet the tank layup goals. The bottom third of the strategies could be eliminated from further consideration or the strategies could be reconfigured to combine elements into a strategy or strategies oriented at meeting the tank lay-up goals. 
Table 3. Team Member Rankings (2 Sheets)

\begin{tabular}{|c|c|c|c|c|c|c|c|c|}
\hline $\mathbf{A}$ & B & C & D & $\mathbf{E}$ & $\mathbf{F}$ & G & H & $\mathbf{I}$ \\
\hline $\begin{array}{l}\text { Trench/Infiltration } \\
\text { Barrier/ } \\
\text { Drying/Enhanced } \\
\text { Pumping }\end{array}$ & Waste Removal & Waste Removal & $\begin{array}{l}\text { Trench/Infiltration } \\
\text { Barrier/ } \\
\text { Drying/Enhanced } \\
\text { Pumping }\end{array}$ & $\begin{array}{l}\text { Interceptor } \\
\text { Trench/Drying }\end{array}$ & $\begin{array}{l}\text { Low Strength } \\
\text { Grout/Drying }\end{array}$ & $\begin{array}{l}\text { Low Strength } \\
\text { Grout/Drying }\end{array}$ & $\begin{array}{l}\text { Trench/Infiltration } \\
\text { Barrier/Drying }\end{array}$ & $\begin{array}{l}\text { Interceptor } \\
\text { Trench/Drying }\end{array}$ \\
\hline $\begin{array}{l}\text { Trench/Infiltration } \\
\text { Barrier/Drying }\end{array}$ & Vault Drying & $\begin{array}{l}\text { Trench/Infiltration } \\
\text { Barrier/Drying }\end{array}$ & $\begin{array}{l}\text { Low Strength } \\
\text { Grout/Drying }\end{array}$ & $\begin{array}{l}\text { Trench/Infiltration } \\
\text { Barrier/Drying }\end{array}$ & Low Strength Grout & Low Strength Grout & $\begin{array}{l}\text { Trench/Infiltration } \\
\text { Barrier/ } \\
\text { Drying/Enhanced } \\
\text { Pumping }\end{array}$ & $\begin{array}{l}\text { Contamination } \\
\text { Fixative/Drying }\end{array}$ \\
\hline $\begin{array}{l}\text { Groundwater } \\
\text { Barrier/Drying }\end{array}$ & Vault \& Tank Drying & Low Strength Grout & Current System & Nitrogen Blanket & $\begin{array}{l}\text { Contamination } \\
\text { Fixative/Drying }\end{array}$ & $\begin{array}{l}\text { Vault \& Tank } \\
\text { Drying }\end{array}$ & Vault \& Tank Drying & Vault Drying \\
\hline $\begin{array}{l}\text { Infiltration } \\
\text { Barrier/Drying }\end{array}$ & $\begin{array}{l}\text { Trench/Infiltration } \\
\text { Barrier/Drying }\end{array}$ & $\begin{array}{l}\text { Corrosion Inhibitors in } \\
\text { Vault }\end{array}$ & Low Strength Grout & Sorbents in Annulus & Monitors & Waste Removal & Waste Removal & $\begin{array}{l}\text { Trench/Infiltration } \\
\text { Barrier/Drying }\end{array}$ \\
\hline Vault \& Tank Drying & $\begin{array}{l}\text { Trench/Infiltration } \\
\text { Barrier/ } \\
\text { Drying/Enhanced } \\
\text { Pumping }\end{array}$ & Cathodic Protection & Waste Removal & Low Strength Grout & $\begin{array}{l}\text { Groundwater } \\
\text { Barrier/Drying }\end{array}$ & Current System & $\begin{array}{l}\text { Low Strength } \\
\text { Grout/Drying }\end{array}$ & $\begin{array}{l}\text { Infiltration } \\
\text { Barrier/Drying }\end{array}$ \\
\hline $\begin{array}{l}\text { Interceptor } \\
\text { Trench/Drying }\end{array}$ & $\begin{array}{l}\text { Sorbents with } \\
\text { Cathodic Protection }\end{array}$ & Current System & $\begin{array}{l}\text { Trench/Infiltration } \\
\text { Barrier/Drying }\end{array}$ & $\begin{array}{l}\text { Infiltration } \\
\text { Barrier/Drying }\end{array}$ & $\begin{array}{l}\text { Interceptor } \\
\text { Trench/Drying }\end{array}$ & $\begin{array}{l}\text { Infiltration } \\
\text { Barrier/Drying }\end{array}$ & $\begin{array}{l}\text { Interceptor } \\
\text { Trench/Drying }\end{array}$ & Vault \& Tank Drying \\
\hline $\begin{array}{l}\text { Corrosion Inhibitors in } \\
\text { Vault }\end{array}$ & Sorbents in Annulus & $\begin{array}{l}\text { Low Strength } \\
\text { Grout/Drying }\end{array}$ & $\begin{array}{l}\text { Infiltration } \\
\text { Barrier/Drying }\end{array}$ & Monitors & $\begin{array}{l}\text { Trench/Infiltration } \\
\text { Barrier/Drying }\end{array}$ & $\begin{array}{l}\text { Trench/Infiltration } \\
\text { Barrier/Drying }\end{array}$ & $\begin{array}{l}\text { Infiltration } \\
\text { Barrier/Drying }\end{array}$ & $\begin{array}{l}\text { Trench/Infiltration } \\
\text { Barrier/ } \\
\text { Drying/Enhanced } \\
\text { Pumping }\end{array}$ \\
\hline $\begin{array}{l}\text { Nitrogen Blanket } \\
\text { w/Oxygen Removal }\end{array}$ & $\begin{array}{l}\text { Nitrogen Blanket } \\
\text { w/Oxygen Removal }\end{array}$ & Vault \& Tank Drying & Vault Drying & Current System & $\begin{array}{l}\text { Sorbents with } \\
\text { Cathodic Protection }\end{array}$ & $\begin{array}{l}\text { Argon Blanket } \\
\text { w/Cathodic } \\
\text { Protection }\end{array}$ & Vault Drying & Waste Removal \\
\hline $\begin{array}{l}\text { Argon Blanket } \\
\text { w/Cathodic Protection }\end{array}$ & Nitrogen Blanket & Sorbents in Annulus & $\begin{array}{l}\text { Groundwater } \\
\text { Barrier/Drying }\end{array}$ & $\begin{array}{l}\text { Low Strength } \\
\text { Grout/Drying }\end{array}$ & $\begin{array}{l}\text { Argon Blanket } \\
\text { w/Cathodic Protection }\end{array}$ & $\begin{array}{l}\text { Trench/Infiltration } \\
\text { Barrier/ } \\
\text { Drying/Enhanced } \\
\text { Pumping }\end{array}$ & $\begin{array}{l}\text { Groundwater } \\
\text { Barrier/Drying }\end{array}$ & $\begin{array}{l}\text { Corrosion Inhibitors in } \\
\text { Vault }\end{array}$ \\
\hline Cathodic Protection & Monitors & Vault Drying & Vault \& Tank Drying & Argon Blanket & $\begin{array}{l}\text { Trench/Infiltration } \\
\text { Barrier/ } \\
\text { Drying/Enhanced } \\
\text { Pumping }\end{array}$ & $\begin{array}{l}\text { Contamination } \\
\text { Fixative/Drying }\end{array}$ & $\begin{array}{l}\text { Contamination } \\
\text { Fixative/Drying }\end{array}$ & $\begin{array}{l}\text { Groundwater } \\
\text { Barrier/Drying }\end{array}$ \\
\hline Sorbents in Annulus & $\begin{array}{l}\text { Low Strength } \\
\text { Grout/Drying }\end{array}$ & Nitrogen Blanket & $\begin{array}{l}\text { Corrosion Inhibitors in } \\
\text { Vault }\end{array}$ & $\begin{array}{l}\text { Sorbents with } \\
\text { Cathodic Protection }\end{array}$ & Current System & Cathodic Protection & $\begin{array}{l}\text { Nitrogen Blanket } \\
\text { w/Oxygen Removal }\end{array}$ & $\begin{array}{l}\text { Low Strength } \\
\text { Grout/Drying }\end{array}$ \\
\hline Vault Drying & Low Strength Grout & Argon Blanket & $\begin{array}{l}\text { Argon Blanket } \\
\text { w/Cathodic Protection }\end{array}$ & $\begin{array}{l}\text { Nitrogen Blanket } \\
\text { w/Oxygen Removal }\end{array}$ & $\begin{array}{l}\text { Nitrogen Blanket } \\
\text { w/Oxygen Removal }\end{array}$ & Vault Drying & Nitrogen Blanket & Current System \\
\hline
\end{tabular}


Table 3. Team Member Rankings (2 Sheets)

\begin{tabular}{|c|c|c|c|c|c|c|c|c|}
\hline $\mathbf{A}$ & B & $\mathbf{C}$ & D & $\mathbf{E}$ & $\mathbf{F}$ & $\mathbf{G}$ & $\mathbf{H}$ & $\mathbf{I}$ \\
\hline $\begin{array}{l}\text { Sorbents with } \\
\text { Cathodic Protection }\end{array}$ & $\begin{array}{l}\text { Interceptor } \\
\text { Trench/Drying }\end{array}$ & $\begin{array}{l}\text { Argon Blanket } \\
\text { w/Cathodic Protection }\end{array}$ & $\begin{array}{l}\text { Interceptor } \\
\text { Trench/Drying }\end{array}$ & $\begin{array}{l}\text { Trench/Infiltration } \\
\text { Barrier/ } \\
\text { Drying/Enhanced } \\
\text { Pumping }\end{array}$ & Vault Drying & $\begin{array}{l}\text { Sorbents with } \\
\text { Cathodic Protection }\end{array}$ & Low Strength Grout & Low Strength Grout \\
\hline Monitors & $\begin{array}{l}\text { Infiltration } \\
\text { Barrier/Drying }\end{array}$ & $\begin{array}{l}\text { Sorbents with } \\
\text { Cathodic Protection }\end{array}$ & $\begin{array}{l}\text { Contamination } \\
\text { Fixative/Drying }\end{array}$ & $\begin{array}{l}\text { Corrosion Inhibitors in } \\
\text { Vault }\end{array}$ & Waste Removal & Monitors & $\begin{array}{l}\text { Corrosion Inhibitors in } \\
\text { Vault }\end{array}$ & $\begin{array}{l}\text { Nitrogen Blanket } \\
\text { w/Oxygen Removal }\end{array}$ \\
\hline Current System & $\begin{array}{l}\text { Groundwater } \\
\text { Barrier/Drying }\end{array}$ & $\begin{array}{l}\text { Nitrogen Blanket } \\
\text { w/Oxygen Removal }\end{array}$ & Nitrogen Blanket & Waste Removal & Argon Blanket & $\begin{array}{l}\text { Nitrogen Blanket } \\
\text { w/Oxygen Removal }\end{array}$ & Current System & Nitrogen Blanket \\
\hline Argon Blanket & Current System & $\begin{array}{l}\text { Infiltration } \\
\text { Barrier/Drying }\end{array}$ & Cathodic Protection & Cathodic Protection & Vault \& Tank Drying & $\begin{array}{l}\text { Groundwater } \\
\text { Barrier/Drying }\end{array}$ & Cathodic Protection & Monitors \\
\hline Nitrogen Blanket & $\begin{array}{l}\text { Corrosion Inhibitors in } \\
\text { Vault }\end{array}$ & $\begin{array}{l}\text { Trench/Infiltration } \\
\text { Barrier/ } \\
\text { Drying/Enhanced } \\
\text { Pumping }\end{array}$ & Argon Blanket & Vault \& Tank Drying & Nitrogen Blanket & $\begin{array}{l}\text { Corrosion } \\
\text { Inhibitors in Vault }\end{array}$ & Argon Blanket & Cathodic Protection \\
\hline $\begin{array}{l}\text { Contamination } \\
\text { Fixative/Drying }\end{array}$ & $\begin{array}{l}\text { Contamination } \\
\text { Fixative/Drying }\end{array}$ & $\begin{array}{l}\text { Contamination } \\
\text { Fixative/Drying }\end{array}$ & $\begin{array}{l}\text { Nitrogen Blanket } \\
\text { w/Oxygen Removal }\end{array}$ & $\begin{array}{l}\text { Groundwater } \\
\text { Barrier/Drying }\end{array}$ & $\begin{array}{l}\text { Infiltration } \\
\text { Barrier/Drying }\end{array}$ & $\begin{array}{l}\text { Sorbents in } \\
\text { Annulus }\end{array}$ & $\begin{array}{l}\text { Sorbents with } \\
\text { Cathodic Protection }\end{array}$ & $\begin{array}{l}\text { Sorbents with } \\
\text { Cathodic Protection }\end{array}$ \\
\hline Waste Removal & Cathodic Protection & Monitors & $\begin{array}{l}\text { Sorbents with } \\
\text { Cathodic Protection }\end{array}$ & Vault Drying & Sorbents in Annulus & $\begin{array}{l}\text { Interceptor } \\
\text { Trench/Drying }\end{array}$ & Monitors & Sorbents in Annulus \\
\hline $\begin{array}{l}\text { Low Strength } \\
\text { Grout/Drying }\end{array}$ & $\begin{array}{l}\text { Argon Blanket } \\
\text { w/Cathodic Protection }\end{array}$ & $\begin{array}{l}\text { Interceptor } \\
\text { Trench/Drying }\end{array}$ & Monitors & $\begin{array}{l}\text { Argon Blanket } \\
\text { w/Cathodic Protection }\end{array}$ & Cathodic Protection & Argon Blanket & $\begin{array}{l}\text { Argon Blanket } \\
\text { w/Cathodic Protection }\end{array}$ & Argon Blanket \\
\hline Low Strength Grout & Argon Blanket & $\begin{array}{l}\text { Groundwater } \\
\text { Barrier/Drying }\end{array}$ & Sorbents in Annulus & $\begin{array}{l}\text { Contamination } \\
\text { Fixative/Drying }\end{array}$ & $\begin{array}{l}\text { Corrosion Inhibitors in } \\
\text { Vault }\end{array}$ & Nitrogen Blanket & Sorbents in Annulus & $\begin{array}{l}\text { Argon Blanket } \\
\text { w/Cathodic Protectiol }\end{array}$ \\
\hline
\end{tabular}


Table 4. Combined Rankings of Team Members

\begin{tabular}{|c|c|c|c|c|c|c|}
\hline $\begin{array}{c}\text { Sorted by Rankings } \\
\text { Score }\end{array}$ & Ranked \#1 & Ranked \#2 & Ranked \#3 & Ranked \#4 & Ranked \#5 & $\begin{array}{l}\text { Rankings } \\
\text { Score }\end{array}$ \\
\hline $\begin{array}{l}\text { Trench/Infiltration } \\
\text { Barrier/Drying }\end{array}$ & 1 & 3 & 2 & 0 & 0 & 23 \\
\hline $\begin{array}{l}\text { Trench/Infiltration } \\
\text { Barrier/Drying/ } \\
\text { Enhanced Pumping }\end{array}$ & 2 & 1 & 0 & 1 & 0 & 16 \\
\hline $\begin{array}{l}\text { Low Strength } \\
\text { Grout/Drying }\end{array}$ & 2 & 1 & 0 & 0 & 1 & 15 \\
\hline Waste Removal & 2 & 0 & 0 & 2 & 1 & 15 \\
\hline Low Strength Grout & 0 & 2 & 1 & 1 & 1 & 14 \\
\hline $\begin{array}{l}\text { Interceptor } \\
\text { Trench/Drying }\end{array}$ & 2 & 0 & 0 & 0 & 0 & 10 \\
\hline Vault \& Tank Drying & 0 & 0 & 3 & 0 & 1 & 10 \\
\hline $\begin{array}{l}\text { Contamination } \\
\text { Fixative/Drying }\end{array}$ & 0 & 1 & 1 & 0 & 0 & 7 \\
\hline Vault Drying & 0 & 1 & 1 & 0 & 0 & 7 \\
\hline Current System & 0 & 0 & 1 & 0 & 1 & 4 \\
\hline $\begin{array}{l}\text { Groundwater } \\
\text { Barrier/Drying }\end{array}$ & 0 & 0 & 1 & 0 & 1 & 4 \\
\hline $\begin{array}{l}\text { Infiltration } \\
\text { Barrier/Drying }\end{array}$ & 0 & 0 & 0 & 1 & 1 & 3 \\
\hline Nitrogen Blanket & 0 & 0 & 1 & 0 & 0 & 3 \\
\hline $\begin{array}{l}\text { Corrosion Inhibitors in } \\
\text { Vault }\end{array}$ & 0 & 0 & 0 & 1 & 0 & 2 \\
\hline Monitors & 0 & 0 & 0 & 1 & 0 & 2 \\
\hline Sorbents in Annulus & 0 & 0 & 0 & 1 & 0 & 2 \\
\hline Cathodic Protection & 0 & 0 & 0 & 0 & 1 & 1 \\
\hline Argon Blanket & & & & & & 0 \\
\hline $\begin{array}{l}\text { Argon Blanket } \\
\text { w/Cathodic Protection }\end{array}$ & & & & & & 0 \\
\hline $\begin{array}{l}\text { Nitrogen Blanket } \\
\text { w/Oxygen Removal }\end{array}$ & & & & & & 0 \\
\hline $\begin{array}{l}\text { Sorbents with Cathodic } \\
\text { Protection }\end{array}$ & & & & & & 0 \\
\hline
\end{tabular}


The scores provided by the team for weighting factors for each criterion are shown in Table 5 . Table 5 also shows the variation in scores (range) and a calculated average (mean) and median for each criterion. There was a very wide disparity in several of the weighting factors.

The range for some was from 1 to 5 . Again, this is something that should be discussed by team members to understand the basis for the differences. The criterion that scored highest was Prevent Release of Tank Contents. Other criteria that scored high were:

- Acceptable Long-Term Risk

- Maintain Tank Integrity

- Acceptable Short-Term Risk

- Safe Operating Envelope

- Preserve Closure Options.

\subsection{SENSITIVITY ANALYSIS}

As long as there are a relatively large number of people scoring the strategies (eight or more), average weighting factors and average scores can be used to determine a ranking order from the scoring sheets. High and low scores for weighting factors and each strategy should not be discarded, but should be discussed (Letter \#3). 
Table 5. Weighting Factor Averages

\begin{tabular}{|c|c|c|c|c|c|c|c|c|c|c|c|c|c|c|}
\hline $\begin{array}{c}\text { Evaluation } \\
\text { Criteria----> }\end{array}$ & $\begin{array}{l}\text { Compliance } \\
\text { with } \\
\text { Regulations } \\
\text { and Permits }\end{array}$ & $\begin{array}{l}\text { Prevent } \\
\text { Release of } \\
\text { Contents }\end{array}$ & $\begin{array}{c}\text { Acceptable } \\
\text { Risk (Short } \\
\text { Term) }\end{array}$ & $\begin{array}{c}\text { Acceptable } \\
\text { Risk } \\
\text { (Long } \\
\text { Term) }\end{array}$ & $\begin{array}{c}\text { Maintain } \\
\text { Tank } \\
\text { Integrity }\end{array}$ & $\begin{array}{c}\text { Safe } \\
\text { Operating } \\
\text { Envelope }\end{array}$ & $\begin{array}{c}\text { Capital } \\
\text { Cost }\end{array}$ & $\begin{array}{l}\text { Operating } \\
\text { Cost }\end{array}$ & $\begin{array}{c}\text { Proven } \\
\text { Methods and } \\
\text { Technologies }\end{array}$ & $\begin{array}{c}\text { Minimize } \\
\text { Secondary } \\
\text { Waste }\end{array}$ & $\begin{array}{c}\text { Preserve } \\
\text { Closure } \\
\text { Options }\end{array}$ & $\begin{array}{l}\text { Regulatory } \\
\text { and } \\
\text { Stakeholder } \\
\text { Acceptance }\end{array}$ & $\begin{array}{c}\text { Reduced } \\
\text { Monitoring } \\
\text { and } \\
\text { Surveillance }\end{array}$ & $\begin{array}{c}\text { Certainty } \\
\text { of Strategy }\end{array}$ \\
\hline
\end{tabular}

Team Member

\begin{tabular}{|c|c|c|c|c|c|c|c|c|c|c|c|c|c|c|}
\hline B & Did not sul & tings & & & & & & & & & & & & \\
\hline $\mathrm{C}$ & Did not we & & & & & & & & & & & & & \\
\hline A & 1 & 5 & 4 & 4 & 5 & 3 & 4 & 3 & 4 & 5 & 4 & 2 & 3 & 4 \\
\hline $\mathrm{E}$ & 5 & 5 & 5 & 5 & 4 & 5 & 3 & 3 & 4 & 3 & 4 & 4 & 3 & 4 \\
\hline $\mathrm{F}$ & 4 & 5 & 4 & 4 & 4 & 4 & 3 & 3 & 3 & 4 & 4 & 4 & 2 & 3 \\
\hline G & 4 & 5 & 4 & 5 & 3 & 4 & 2 & 3 & 4 & 3 & 4 & 4 & 1 & 4 \\
\hline $\mathrm{H}$ & 5 & 5 & 4 & 4 & 5 & 5 & 3 & 2 & 4 & 2 & 5 & 4 & 3 & 4 \\
\hline I & 5 & 5 & 2 & 3 & 5 & 2 & 2 & 4 & 3 & 4 & 3 & 3 & 2 & 2 \\
\hline Mean (Average) & 3.7 & 4.7 & 4.0 & 4.3 & 4.3 & 4.0 & 2.9 & 3.0 & 3.4 & 3.1 & 4.0 & 3.4 & 2.3 & 3.7 \\
\hline Median & 4.0 & 5.0 & 4.0 & 4.0 & 4.0 & 4.0 & 3.0 & 3.0 & 4.0 & 3.0 & 4.0 & 4.0 & 2.0 & 4.0 \\
\hline Range & $1-5$ & $3-5$ & $2-5$ & $3-5$ & $3-5$ & $2-5$ & $2-4$ & $2-4$ & $2-4$ & $1-5$ & $3-5$ & $2-4$ & $1-3$ & $2-5$ \\
\hline
\end{tabular}




\subsection{UNCERTAINTY OF STRATEGIES}

After the alternative strategies and evaluation criteria were identified, it was apparent that information gaps made evaluation and ranking of the strategies difficult. The effectiveness and acceptability of several of the options are not fully developed. The principal information needs identified to reduce the uncertainties are listed below.

- A better estimate of the remaining corrosion allowance for the tanks.

- An estimate of the maximum rate of surface runoff from rain and/or snowmelt to establish the size of an interceptor trench in order to determine a cost estimate for that option. Are there existing storm sewers or other drainage systems?

- Data and analysis to establish if pumping from below the vaults alone would reduce groundwater infiltration into the vaults to a rate low enough for a drying system to be effective.

- Determination of whether maintaining a liquid inventory inside the tanks with continued chemistry adjustments is adequate to control internal corrosion.

- Determination of whether effective control of the oxygen concentration in the gas in the annuli alone can control external corrosion within an acceptable rate. If so, is an oxygen removal system needed or will a better inert gas system suffice?

- Determine if a system to maintain the vaults and all external surfaces of the tanks in a dry condition is necessary to ensure an acceptable corrosion rate. The primary concern is keeping the bottoms of the tanks dry.

- Determine if a tank wall penetration must be prevented during lay-up or if small penetrations that would not result in releases outside the tanks or vaults would be acceptable.

- Resolution of the technical and engineering issues related to cathodic protection.

- Determination of the acceptability of using argon rather than nitrogen due to the higher cost and safety concerns.

- Determination of whether the pumps in the catch pans need to be relocated to be at the lowest point.

- Determine if sorbent material(s) could capture all leaking radionuclides of concern.

- Estimates of the expected life of potential groundwater barrier systems.

- A more detailed assessment of adding and maintaining corrosion inhibitors in the water in the vault.

- Feasibility of decontamination prior to lay-up precluding the need for any further preparation for lay-up. 
- Updates to existing preliminary cost estimates and new preliminary cost estimates for several options, including:

- Installation of an interceptor trench or an underground barrier

- Installation of an infiltration barrier

- Addition of a roof above the vaults and tanks

- Installation and operation of an oxygen removal system

- Continuous corrosion monitoring of tanks' external surfaces. 


\subsection{WORKSHOP AT WEST VALLEY DEMONSTRATION PROJECT}

A workshop was held at the West Valley site on June 19, 2001 to discuss the results of methodology demonstration. The meeting attendees included five West Valley Nuclear Services employees, a representative from the Tanks Focus Area, and a representative from Jacobs Engineering Group Inc. The methodology was described and feedback was received from the West Valley Nuclear Services personnel and the Tanks Focus Area customer. The meeting attendees agreed that the methodology was a valid tool for determining a preferred approach and that the methodology could be used to identify preferred options at other U.S. Department of Energy sites.

Some suggestions for improvements to the methodology were offered.

- The terminology of 'options' and 'strategies' was confusing to some of the participants. Use of the terms 'considerations' and 'concepts' was suggested.

- Much of the discussion was on the criteria selected for assessing potential concepts. The group decided that some of the criteria should be identified as go/no go criteria rather than being assigned a weighting factor. The suggested go/no go criteria included: (1) regulatory acceptance, (2) prevent release of tank contents to groundwater, (3) acceptable risk, (4) maintain tank integrity, (5) safe operating envelope, and (6) preserve future closure options. A particular concern for the West Valley site is that the current information is inadequate to judge whether or not several of the alternative approaches would meet all these go/no go criteria.

- A block diagram of the methodology was suggested to aid understanding for use at other sites.

- The meeting attendees reinforced the importance of having a well informed and diverse evaluation team.

- The pros and cons of each consideration and concept should be identified to aid the decision process.

- There were three categories of concepts identified: (1) individual actions, (2) combinations of actions, and (3) phased actions.

- One factor missing in the methodology is a time factor. Time is a consideration in how long it would take to implement a concept and also in phased implementation of the concepts that are combinations of several considerations.

- Monitors (and some other considerations) could be combined with just about any other consideration. Perhaps the considerations could be split into primary and secondary categories.

- The 'Waste Removal' strategy was not felt to be credible by West Valley Nuclear Services personnel. 
- A 'Consumer Report' chart of the results was suggested.

- Some of the team members suggested assigning weighting factors by distribution of a total of 100 points to all the criteria, rather than assigning a factor of 1 to 5 .

- Revisions to the ranking calculated from scores was debated. Some team members felt that the ranking should be modified by consensus from the team, but others felt that would take the objectivity out of the process. The group decided that discussion of the results was healthy and the methodology should be used as a tool to encourage information sharing and that modifications should be allowed as long as the cause for the original ranking is understood.

- A detailed discussion and common understanding of all the proposed concepts and criteria is needed before any scoring begins. This would also lead to identification of information needs to fairly assess all the candidate approaches. This may also identify technology development needs for potentially viable candidates that cannot be implemented until sometime in the future. 


\subsection{CONCLUSIONS AND RECOMMENDATIONS}

The methodology developed for ranking the potential strategies for lay-up of the West Valley Demonstration Project tanks can be used to provide a basis for a decision on the preferred path forward. The methodology will provide a consensus ranking even with wide variations in scores from individual team members as long as the number of team members is large enough. A minimum of 8 team members is recommended, and 10 to 12 members would be better. Because of the number and types of technical issues associated with the strategies, the evaluation team should be comprised of a broad spectrum of technical experts and decision makers.

The current uncertainties associated with several strategies will tend to result in more costly and complex strategies to be favored. Strategy-specific performance data could result in simpler strategies. Also, there may be other strategies and criteria identified during the process that will be ranked higher than most or all of the strategies identified in this report. In the absence of performance data for the strategies, there is a tendency to rank the strategies on a relative basis because the minimum but sufficient effort to meet the tank lay-up goals is unknown.

All the strategies and criteria should be presented to the team members to ensure a common understanding. The team should then determine if additional strategies should be scored and if the decision criteria should be modified. Any changes to the strategies or criteria should be done before the scoring starts. Orientation, scoring, and discussions should be in a facilitated session or sessions.

A difficulty in evaluating the lay-up strategies for the West Valley Demonstration Project tanks is that there is incomplete information on the cost and performance for several of the identified strategies. A recommended path forward would be to reevaluate the strategies identified in this report based on the example ranking and eliminate or reconfigure the strategies that were ranked at or near the bottom. Preconceptual engineering data should be developed for the remaining strategies to facilitate scoring and ranking using this methodology. The team members should be consulted to identify any additional information needs to support making informed decisions. The initial rankings will have to be made based on the available information.

Once each team member scores the alternatives, the scores can be combined and the team members can then be reconvened to discuss the results. Any wide variations among scores should be discussed to ensure there are no errors. This discussion will also help team members share their points of view and expertise or experience on the strategies. The discussion can then focus on the composite ranking to determine if there is consensus. The team members should be allowed to discuss if they feel the list should be modified based on the information shared. The team should develop a final, consensus-ranked list of the top five strategies. The team, West Valley Demonstration Project, and U.S. Department of Energy management should then decide whether to proceed with conceptual design of the top one or two strategies or specify the additional information needed to make a final decision.

The methodology is applicable to determining preferred lay-up approaches at other U.S. Department of Energy sites. Some of the alternative strategies identified for West Valley should also be considered for implementation at the other sites, and some would not be. Each site has unique characteristics that would require unique considerations for lay-up. 


\subsection{REFERENCES}

Chang, J.Y., D.C. Meess, S.M. Barnes, and F.W. Damerow, 1998, "Corrosion Monitoring and Control for Tanks 8D-1, 8D-2 and the Vitrification Melter, Volume 1," The Fifth Annual Technical Review Meeting at West Valley, New York, September 21-22.

Chang, J.Y., D.C. Meess, and S.M. Barnes, 1999, "Corrosion Monitoring and Control for Tanks 8D-1, 8D-2 and the Vitrification Melter, Volume 2," The Sixth Annual Technical Review Meeting at West Valley, New York, September 21-22.

Henderson, C., 2001a, "Contract No. TTP RL30WT21A, Milestone No. A.1-1, "Submittal of Functions and Requirements for WVDP Tank Lay-up," (Letter Report \#1 to Michael Terry, Safety Technology Integration Manager, Tanks Focus Area, PNNL, March 15), Jacobs Engineering Group Inc., Richland, Washington.

Henderson, C., 2001b, "Contract No. TTP RL30WT21A, Milestone No. A.2-1, "Issue Tank Lay-Up Strategies Report for WVDP," (Letter Report \#2 to Michael Terry, Safety Technology Integration Manager, Tanks Focus Area, PNNL, April 16), Jacobs Engineering Group Inc., Richland, Washington.

Henderson, C., 2001c, "Contract No. TTP RL30WT21A, Milestone No. Milestone A.3-1, "Issue Decision Plan for WVDP Tank Lay-Up," (Letter Report \#3 to Michael Terry, Safety Technology Integration Manager, Tanks Focus Area, PNNL, May 25, 2001), Jacobs Engineering Group Inc., Richland, Washington.

Meess, D.C. and J.Y. Chang, 1997, "Corrosion Monitoring and Control for Tanks 8D-1 \& 8D-2," The Fourth Annual Technical Review Meeting at West Valley, New York, September 8-9.

WVNS-DC-065, 1995, Design Criteria - Inert Gas System for HLW Tanks 8D-1 and 8D-2 Vaults, West Valley Nuclear Services, West Valley, New York. 